Tsaqofiya : Jurnal Pendidikan Bahasa dan Sastra Arab

Vol. 4 No. 1 Januari 2022, 45-54

P-ISSN : 2685-7022, E-ISSN : 2685-7103

DOI: $10.21154 /$ tsaqofiya.v4i1.50

\title{
Tren Sastra Eropa dan Keterpengaruhannya Terhadap Sastra Arab (Kajian Sastra Banding)
}

\author{
Angga Mustaka. J.P \\ UIN Sunan Kalijaga, Yogyakarta \\ angga.mjp@gmail.com
}

\section{Abstract}

This article aims to discuss trends in European literature and their influence on Arabic literature, a comparative study of literature. The background of this article departs from the many literary schools in Europe that have an influence on Arabic literature. The research method used is a qualitative method with a historical approach. The data collection technique used is the collection of documents or documentation. The data analysis technique in this article uses the Creswell model of qualitative data analysis. The results of this study are; 1) The literature that pioneered the birth of comparative literary studies is French literature. 2) American literature emerged as a response to French literature. 3) The influence of European literature on Arabic literature can be seen from the characteristics of European poets who are very oriented to the rules and styles of Arabic literature. 4) The influence between European literature and Arabic literature is also due to the large number of Arab writers who migrated to Europe for various reasons.

Keywords: comparative literature, European literary trends, Arabic literature

\section{Abstrak}

Artikel ini bertujuan untuk membahas tren Sastra Eropa serta keterpengaruhannya terhadap Sastra Arab, kajian sastra banding. Adapun latar belakang dari artikel ini berangkat dari banyaknya madzhab-madzhab sastra di Eropa yang mempunyai keterpengaruhan terhadap Sastra Arab. Metode penelitian yang digunakan adalah metode kualitatif dengan pendekatan historis. Teknik pengumpulan data yang digunakan adalah pengumpulan dokumen atau dokumentasi. Teknik analisa data pada artikel ini menggunakan analisa data kualitatif model Creswell. Hasil penelitian ini adalah; 1) Sastra yang mempelopori lahirnya kajian sastra banding yaitu adalah sastra Perancis.2) Sastra Amerika muncul sebagai respon dari Sastra Perancis. 3) Keterpengaruhan Sastra Eropa terhadap Sastra Arab terlihat dari ciri khas para penyair Eropa yang sangat berorientasi pada kaidah-kaidah dan gaya Sastra Arab. 4) Keterpengaruhan antara Sastra Eropa dan Sastra Arab juga disebabkan akibat banyaknya sastrawan Arab yang hijrah ke Eropa dengan berbagai alasan.

Kata Kunci: sastra banding, tren sastra Eropa, sastra Arab 


\section{PENDAHULUAN}

Kajian ilmiah pada karya sastra dapat dikatakan baru bermula pada dekade kedua abad XX, yaitu dengan munculnya sebuah aliran formalism di Rusia yang kemudian dikenal sebagai Formalisme Rusia. Dengan di ilhami oleh apa yang dilakukan oleh Ferdinand de Saussure dalam ilmu bahasa atau linguistik. ${ }^{1}$ Sastra bandingan merupakan salah satu dari sekian banyak pendekatan yang ada dalam ilmu sastra. Pendekatan sastra bandingan pertama kali muncul di Eropa pada awal abad ke-19. Ide tentang sastra bandingan dikemukakan oleh Sante Beuve dalam sebuah artikelnya yang terbit tahun $1868 .^{2}$

Sastra bandingan di dunia memiliki banyak madzhab yang terkenal, diantaranya terdapat madzhab Perancis dan Amerika, tetapi selain dua madzhab tersebut terdapat juga aliran Sastra Rusia, Jerman dan juga Arab yang mempunyai keterpengaruhan terhadap madzhab dan sastra di dunia. Satu hal yang disepakati oleh madzhab sastra bandingan yaitu madzhab tersebut bersepakat bahwa sastra bandingan harus bersifat lintas negara, artinya berusaha membandingkan sastra suatu negara dengan sastra negara lain. Hal ini di dukung oleh pernyataan Endraswara. ${ }^{3}$ Sastra bandingan adalah sebuah studi teks across cultural. Studi ini merupakan upaya interdisipliner, yakni lebih banyak memperhatikan hubungan sastra menurut aspek waktu dan tempat. Dari aspek waktu, sastra bandingan dapat membandingkan dua atau lebih periode yang berbeda. Sedangkan konteks tempat, akan mengikat sastra bandingan menurut wilayah geografis sastra. Konsep ini mempresentasikan bahwa sastra bandingan memang cukup luas. Bahkan, pada perkembangan selanjutnya, konteks sastra bandingan tertuju pada bandingan sastra dengan bidang lain. Bandingan semacam ini, guna merunut keterkaitan antar aspek kehidupan.

Menurut hasil pencarian peneliti terdapat beberapa artikel yang berhubungan dengan artikel ini, diantaranya yaitu: artikel yang berjudul Perkembangan Sejarah dan Isu-Isu Terkini dalam Sastra Bandingan, yang ditulis oleh Dipa Nugraha, UMS, dalam jurnal Diglosia volume 4, nomor 2, tahun 2021, halaman 163-176. Dalam

\footnotetext{
1 Ferdinand de Saussure, Pengantar linguistik umum, Seri Ildep (Bulaksumur, Yogyakarta: Gadjah Mada Univ. Press, 1988), 63-87.

2 Sapardi Djoko Damono, Pegangan penelitian sastra bandingan (Rawamangun, Jakarta: Departemen Pendidikan Nasional, Pusat Bahasa, 2005), 14.

3 Suwardi Endraswara, Metodologi penelitian sastra bandingan, Cet. 1. (Jakarta: Bukupop, 2011), 14.
} 
artikel tersebut membahas terkait sejarah dan isu-isu terkini sastra bandingan, hal ini sejalan dengan apa yang akan dibahas oleh peneliti yang mebedakan antara penelitian tersebut dengan penelitian ini yaitu pada objek kajian dimana pada penelitian tersebut membahas tentang madzhab Cina sedangkan penelitian ini membahas tentang madzhab Eropa. Artikel selanjutnya yang peneliti temukan yaitu Menelisik Kosmopolitanisme Sastra Arab (Kajian Sastra Banding), yang ditulis oleh Tatik Maryatut Tasnimah, UIN Sunan Kalijaga, Yogyakarta, dalam jurnal Adabiyyāt, Vol. 9, No. 1, Juni 2010, dalam artikel tersebut terdapat sub bab yang menjelaskan tentang pengaruh Sastra Arab terhadap sastra asing, yang membedakan dengan penelitian ini adalah fokus penelitian yang disajikan berupa tren-tren Sastra Eropa dan keterpengaruhannya terhadap Sastra Arab secara meluas. Dari paparan latar belakang diatas, penelitian ini mempunyai rumusan masalah terkait pembahasan bagaimana trend sastra di Eropa serta keterpengaruhannya terhadap Sastra Arab?

\section{METODE}

Penelitian ini termasuk penelitian perpustakaan (Library research), yaitu penelitian yang memperoleh data dan informasi tentang objek penelitiannya lewat buku-buku atau alat lainnya. ${ }^{4}$ Data-data yang berasal dari sumber kepustakaan tersebut kemudian dipilah dalam klaster-klaster sesuai dengan tujuan kajian. Datadata tersebut kemudian dianalisis dengan cara reduksi, dispaly data, dan penarikan kesimpulan.

Dalam hal penelitian kualitatif, Creswell ${ }^{5}$ menyatakan bahwa:

Qualitative research is a means for exploring and understanding the meaning individuals or groups ascribe to a social or human problem. The process of research involves emerging questions and procedures; collecting data in the participants' setting; analyzing the data inductively, buiding from particulars to general themes; and making interpretations of the meaning of data. The final written report a flexible writing structure.

Metode penelitian yang digunakan dalam penelitian ini adalah, metode penelitian kualitatif. Metode penelitian kualitatif dapat diartikan sebagai metode penelitian yang berlandaskan pada filsafat postpositivisme, digunakan untuk meneliti pada kondisi obyek yang alamiah, (sebagai lawannya adalah eksperimen) dimana

${ }^{4}$ Riant Nugroho Dwijowijoto, Gender dan strategi pengarus-utamaannya di Indonesia, Cet. 1 (Yogyakarta: Pustaka Pelajar, 2008), 72-73.

${ }^{5}$ John W Creswell, Research Design( Pendeketan kualitatif, kuantitatif, dan mixed) (Yogyakarta: Pustaka Pelajar, 2009). 
peneliti sebagai instrumen kunci, teknik pengumpulan data dilakukan secara triangulasi (gabungan), analisis data bersifat induktif/kualitatif dan hasil penelitian kualitatif lebih menekankan makna dari pada generalisasi.

Adapun teknik pengumpulan data yang digunakan dalam penelitian ini adalah dengan pengumpulan dokumen/dokumentasi. Studi dokumen merupakan pelengkap dari penggunaan metode observasi dan wawancara dalam penelitian kualitatif. Hasil penelitian dari observasi atau wawancara, akan lebih kredibel/dapat dipercaya kalau didukung oleh dokumentasi. ${ }^{6}$ Instrumen penelitian adalah peneliti sendiri. Teknik analisis data kualitatif menggunakan model Creswell, menyediakan data mentah yang berupa transkrip, pandangan peneliti sendiri; mengorganisasikan dan menyimpankan data yang akan dianalisis, membaca seluruh data, menyusun tematema dan deskripsi data, mengkonstruksi antar tema, interpretasi dan memberi makna tema yang telah tersusun. ${ }^{7}$ Pendekatan yang digunakan dalam penelitian ini adalah pendekatan historis. Pendekatan historis mempertimbangkan historisitas karya sastra yang diteliti, pendekatan sejarah menelusuri arti dan makna bahasa sebagaimana yang sudah tertulis, dipahami pada saat ditulis, oleh pengarang yang benar-benar menulis dan sebagainya. Pendekatan historis dengan demikian mempertimbangkan relevansi karya sastra sebagai dokumen sosial. ${ }^{8}$

\section{PEMBAHASAN}

\section{Sejarah Sastra Banding}

Istilah sastra perbandingan adalah terjemahan dari bahasa Inggris, Comparative Literature, atau dari bahasa Perancis, La Litterature Compare. Menurut sejarahnya sastra perbandingan sebagai ilmu, mempunyai dua aliran. Pertama, Aliran Perancis. Aliran ini juga disebut dengan Aliran lama. Dinamakan demikian karena sastra perbandingan itu kelahirannya di Negara Perancis dan dipelopori oleh para pemikir Perancis. Aliran kedua dinamakan Aliran Amerika. Aliran ini dinamakan juga aliran baru. Dinamakan Aliran Baru karena aliran ini mengembangkan Aliran Perancis. ${ }^{9}$

\footnotetext{
${ }^{6}$ Sugiyono, Metode Penelitian Kualitatif, Cet.4 (Bandung: Alfabeta, 2021), 124-25.

7 Sugiyono, 160-61.

${ }^{8}$ Nyoman Kutha Ratna, Teori, metode, dan teknik penelitian sastra, Cet. 4 (Yogyakarta: Pustaka Pelajar, 2008), 65-66.

9 Titiek Suyatmi, Sastra Perbandingan (Yogyakarta: Universitas Ahmad Dahlan Press, 2008), 1.
} 
Di Perancis sastra bandingan dipelopori oleh, misalnya Fernand Baldensperger, Jean-Mari Carre, Paul van Tieghem, dan Marius- Farncois Guyard. Buku-buku yang telah mereka tulis antara lain adalah:

1. La Litteraturre Compare (Paris, 1932:1951) karya Paul van Tieghem. Buku ini berisi uraian mengenai sejarah, teori, masalah dan hasil kesusastraan umum dan perbandingan. Bahan-bahan yang dipakai terbatas pada penerbitan Bahasa Perancis.

2. La Litterature Compare (cetakan pertama, Paris, 1951; edisi kelima, 1969) oleh Marius-Francois Guyard. Buku ini membawa kita pada perkenalan sastra perbandingan yang sealiran dengan Paul van Tieghem.

3. La Litterature Compare depuis un demi diele dalam Annales du Centre UniversitateMediterranean 3 (1951), 69-77, oleh Jean-Marie Carre. Karangan ini penting sebagai kenyataan mewakili Aliran Perancis dalam sastra perbandingan aliran Guyard. Di sini Jean-Marie Carre melihat sastra perbandingan sebagai sesuatu yang berbeda dengan perbandingan kesusastraan atau sastra umum. Dalam karangan ini juga terdapat studi mengenai pengaruh, sejarah perkembangan kesusastraan, sejarah interpretasi kesusastraan dari suatu negara ke negara lain. Di samping itu, juga ditekankan pentingnya kesusastraan itu sendiri. ${ }^{10}$

Aliran Perancis dapat disimpulkan dari buku-buku yang ditulis oleh para tokohnya, berteori bahwa sastra perbandingan adalah pembandingan sastra secara sistematis dari dua Negara yang berlainan. Dalam hal perbandingan ini Aliran Perancis lebih cenderung kepada hal-hal yang dapat dibuktikan dengan hal-hal yang nyata, misalnya, dokumen pribadi pengarang dan menolak kritik sastra sebagai unsur utama dari karya sastra yang hanya memperlihatkan analogi dan perbedaan saja. ${ }^{11}$

Dari skema ini dapat diketahui bahwa konsep sastra perbandingan Aliran Amerika itu agak luas sebab aliran ini membandingkan sastra dengan disiplin di luar sastra. Tetapi hal ini tidak disetujui oleh Aliran Perancis. Perbandingan sastra dengan hal-hal di luar sastra dianggap oleh Aliran Perancis sebagai seni perbandingan dan bukan sastra perbandingan. Alasannya, kajian seperti ini akan mewujudkan kajian yang tidak ilmiah dan menurunkan derajad sastra perbandingan sebagai ilmu yang

\footnotetext{
10 Suyatmi, 2.

11 Suyatmi, 3.
} 
berwibawa. Namun demikian, dalam praktek, Aliran Perancis juga melaksanakan konsep Aliran Amerika. Hal ini tampak dalam judul-judul karangan mereka. ${ }^{12}$

Menurut Aliran Amerika, sastra perbandingan itu pada mulanya muncul dalam studi sastra lisan, khusunya dalam bidang sastra rakyat. Dalam bidang ini cerita rakyat dicari asal usulnya, daerah penyebarannya, dan transformasinya ke sastra tulis. 13

\section{Tren Sastra Di Eropa dan Keterpengaruhannya Terhadap Sastra Arab}

\section{a. Pengertian Tren}

Tren menurut Kamus Besar Bahasa Indonesia (KBBI) adalah bentuk nominal yang berartikan gaya mutakhir. ${ }^{14}$ Tren dalam sastra yang dimaksud disini adalah gaya atau ciri dari sastra tersebut.

\section{b. Sastra Rusia/Slafiya}

Secara gamblang tidak terdapat madrasah slafiya secara khusus tetapi terdapat nilai-nilai dari pemikiran sosiologi, dan madrasah slafiya merupakan pengaruh dari madrasah Perancis dan Amerika dalam perkembangan sastra banding, yang tidak hanya sebatas metodologi tetapi melalui corak, materi dan ideologi. Seperti yang ditulis oleh (كلود بيشوا) awal muncul dan perkembangan slafiya:

Terdapat asumsi bahwa Eropa bagian selatan pada tahun 1945 merupakan suatu daerah tersendiri sampai masa akhir periode tersebut terpecah karena pengaruh politik. Dan hubungan sejarah tersebut memberikan pengaruh terhadap sosial dan budaya yang menyisakan pemikiran dan ideologi setelah terjadinya perpecahan. Sejak tahun 1955 berubahlah menjadi yang kita kenal menjadi sastra Rusia. $^{15}$

Dari perkataan (كلود بيشوا) pengaruh politik terhadap sastra banding merupakan aspek yang tidak bisa disalahkan karena perkembangan sejarah merupakan kesatuan dari perkembangan budaya dan munculnya sastra banding.

\footnotetext{
12 Suyatmi, 4.

13 Rene Wellek dan Austin Warren, Teori Kesusastraan, Cet. 3 (Jakarta: Gramedia Pustaka Utama, 1993), 47.

14 "Arti kata tren - Kamus Besar Bahasa Indonesia (KBBI) Online," diakses 21 Desember 2021, https://kbbi.web.id/tren.

15 Said Alwiiys, Madaris Al Adab Al Muqaran Dirasah Minhu, Cet.1 (Kairo: Pusat Kebudayaan Arab press, 1987), 127.
} 
Kesadaran transendensi patriotisme, penolakan daerah, dan pengakuan bahwa peradaban manusia dan pertukaran nilai-nilainya tidak dapat dipahami dan dirasakan tanpa ada pertukaran referensi. Yang disebabkan batas geografis dan sejarah politik terhadap pengaruh budaya eropa selatan dan sebagian utara. ${ }^{16}$

\section{c. Sastra Jerman}

Sesungguhnya Budaya Arab dan Islam mempunyai pengaruh penting terhadap "واسع " pemikiran orang-orang Eropa. Seperti yang dikatakan oleh Abd rahman badawi المدى tidak hanya dalam filsafat ilmu kedokteran, fisika, olahraga tetapi juga pada sastra: syiir, cerpen dan juga musik.

Sastra jerman yang muncul pada masa pertengahan, masa humanisme. Kemudian munculah tren modern pada abad ke-20. Dan diantara sasra-sastra dunia

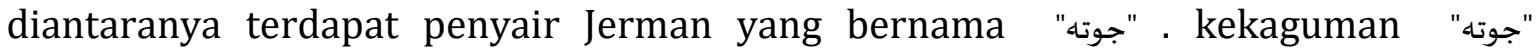
terhadap Arab klasik, dan dengan penyair-penyair Arab terdahulu bahwasanya Bangsa Arab dengan pemikiranya "bangsa yang membangun kejayaanya melalui kitab klasik yang diwariskan, dan berpegang teguh terhadap adat dan pengetahuan yang ada padanya sejak dahulu" diantara aspek yang menjadi perhatiannya yaitu: kebangaan diri (الفخر بالنفس), dan (الإعتزاز بطرائق حياة الأباء) yang mempengaruhi perasaan dengan syiir melalui bahasa dan kemampuan cara kiasan dan imajinasi.

Seperti yang dikatakan pengarang "كاتارينا مومزن terdapat banyak faktor yang menjelaskan "جوته" dengan budaya Arab dan pemikiran Islam, refleksi ayat-ayat AlQuran, kehidupan Nabi Muhammad, dan kutipan-kutipan indah dari kisah nabi.

Dan diantara faktor-faktor yang mempengaruhi pengarang dalam kitabnya

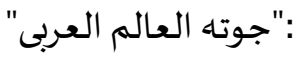

1. Pengamatan studi Arab terhadap orientalis yang mempelajari sastra dengan bahasa Arab.

2. Syair jahiliy.

3. Pengaruh kuat terhadap diwan "اليغربي - الشرقى" .

4. Pujian terhadap syair jahiliy terhdap Al Taliqot dan Al Abhas.

5. Kutipan dari Al-quran dan nasehat nabi. 

6. Mengikuti syair diwan "بحافظ القرآن" .
7. Pengaruh Al-quran dalam kasidah diwan "الشرقى".
8. Syair diwan mengandung hukum-hukum Islam. ${ }^{17}$

\section{d. Sastra Perancis}

Sebagai sebuah ilmu modern Sastra Banding muncul pada abad ke-19 di Prancis. Mungkin tepatnya sekitar tahun 1828 M, yang diprakarsai oleh profesor Abel Villemain ketika menyampaikan perkuliah di Universitas Sorbon, Prancis. Dalam perkuliahannya beliau menyampaikan tentang pengaruh dan keterpengaruhan dalam sastra, dan di antara topiknya: "bab tentang dampak yang ditinggalkan oleh sebuah buku prancis pada abad ke-18 M pada literatur lain dan pada mentalitas Eropa pada umumnya. ${ }^{18}$

Kajian sastra banding ini terus semakin berkembang. Pada tahun $1830 \mathrm{M}$ Jean-Jacques Amber terlihat menyampaikan perkuliahan sastra bandingan di Marseille. Dua tahun kemudian ia pindah ke Paris untuk memberikan kuliah di Sorbone tentang Sastra Prancis dan hubungannya dengan sastra-sastra asing selama berabad-abad. Pada tahun 1835 M, artikel Philaret Schall muncul di majalah Paris, menegaskan kekuatan hubungan antara sastra-sastra Eropa.

Joseph Texte adalah orang pertama yang mengambil alih tribun Lyon, yang didirikan pada tahun 1896 M, dan dia mengikuti jejak gurunya Prontier, dan menulis studi mendalam tentang Sastra Banding yang dia kumpulkan dengan judul (Kajian Sastra Eropa) di 1898 M, dan hal ini memiliki dampak yang kuat pada pertumbuhan Sastra Banding. Texte sangat antusias dalam megkaji Sastra Banding. Namun, sangat disayangkan dia meninggal pada usia tiga puluh lima (1900 M), dan dia tidak memiliki kesempatan untuk menyempurnakan pengaruhnya.

Selanjutnya Texte digantikan di mimbar Lyon oleh peneliti Fernand Baldensperger, yang menulis buku (Goethe di Prancis) pada tahun 1904 M. Kemudian ia diangkat menjadi guru besar di Sorbon ketika membicarakan kedudukan Sastra Banding pada tahun $1910 \mathrm{M}$, dan pada saat yang sama pengindeksan pertama sumber Sastra Banding muncul dari Prancis (Betz) pada tahun 1900 M. Ketika ia meninggal

17 Sobir Abd Ad Dayim, Adab Al Muqaran Baina At Turats Wa Al Muasiroh, Cet 2 (Mesir: Fakultas Bahasa Arab Universitas Zagazig, 2003), 89.

${ }^{18}$ Hisam Khatib, Afaqu Al Adab Al Muqaran Arabiyan wa Aalamiyan, Cet 1 (Damaskus, Beirut: Darul Fikr Press, 1992), 70. 
pada tahun 1903, Baldensperger menyelesaikan pekerjaannya dan mengumpulkan banyak penelitian yang bermanfaat. Beberapa sumber menunjukkan bahwa pengindeksan Betz muncul pada tahun 1897.

Betz telah memilih profesor texte untuk menulis pengantar indeks ini, dan dalam pengantar muncul pernyataan tentang jenis mata pelajaran yang dibahas dalam sastra banding, yang pertama masalah teoritis dan masalah umum, kedua cerita rakyat atau cerita rakyat perbandingan, ketiga studi banding sastra modern, dan keempat, sejarah sastra yang komprehensif sepanjang waktu dan tempat.

Menurut aliran Prancis Sastra Banding adalah ilmu yang mengkaji sejarah berdasarkan hubungan eksternal antar sastra. atau ilmu yang mengkaji hubungan pengaruh dan keterpengaruhan atau pengaruh timbal balik antar sastra nasional dengan metode ilmiah yang ketat. ${ }^{19}$

\section{SIMPULAN}

Berdasarkan hasil pembahasan di atas, maka dapat ditarik kesimpulan sebagai berikut:

1. Sastra yang mempelopori lahirnya kajian sastra banding yaitu sastra Perancis, yang mengatakan bahwa karya sastra dapat dibandingkan dengan karya sastra lain dengan syarat mempunyai perbedaan bahasa dan letak geografis.

2. Sastra Amerika muncul sebagai respon dari Sastra Perancis dengan gagasannya yaitu bahwa karya sastra dapat dibandingkan dengan disiplin ilmu lain selain sastra, seperti filsafat, sosiologi dll.

3. Keterpengaruhan Sastra Eropa terhadap Sastra Arab terlihat dari ciri khas para penyair Eropa yang sangat berorientasi pada kaidah-kaidah dan gaya Sastra Arab.

4. Keterpengaruhan antara Sastra Eropa dan Sastra Arab juga disebabkan akibat banyaknya sastrawan Arab yang hijrah ke Eropa dengan berbagai alasan sehingga terciptanya percampuran, atau keterpengaruhan budaya di dalam karya sastra Eropa maupun Karya Sastra Arab.

19 Tohir Ahmad Makiy, Muqadimaah Fi Al Adab Al Islamiy Al Muqaran (Mesir: Universitas Kairo Press, 1994), 6. 


\section{DAFTAR PUSTAKA}

Ad Dayim, Sobir Abd. Adab Al Muqaran Baina At Turats Wa Al Muasiroh. Cet 2. Mesir: Fakultas Bahasa Arab Universitas Zagazig, 2003.

Alwiiys, Said. Madaris Al Adab Al Muqaran Dirasah Minhu. Cet.1. Kairo: Pusat Kebudayaan Arab press, 1987.

“Arti kata tren - Kamus Besar Bahasa Indonesia (KBBI) Online.” Diakses 21 Desember 2021. https://kbbi.web.id/tren.

Creswell, John W. Research Design (Pendeketan kualitatif, kuantitatif, dan mixed). Yogyakarta: Pustaka Pelajar, 2009.

Damono, Sapardi Djoko. Pegangan penelitian sastra bandingan. Rawamangun, Jakarta: Departemen Pendidikan Nasional, Pusat Bahasa, 2005.

Dwijowijoto, Riant Nugroho. Gender dan strategi pengarus-utamaannya di Indonesia. Cet. 1. Yogyakarta: Pustaka Pelajar, 2008.

Endraswara, Suwardi. Metodologi penelitian sastra bandingan. Cet. 1. Jakarta: Bukupop, 2011.

Khatib, Hisam. Afaqu Al Adab Al Muqaran Arabiyan wa Aalamiyan. Cet 1. Damaskus, Beirut: Darul Fikr Press, 1992.

Makiy, Tohir Ahmad. Muqadimaah Fi Al Adab Al Islamiy Al Muqaran. Mesir: Universitas Kairo Press, 1994.

Ratna, Nyoman Kutha. Teori, metode, dan teknik penelitian sastra. Cet. 4. Yogyakarta: Pustaka Pelajar, 2008.

Saussure, Ferdinand de. Pengantar linguistik umum. Seri Ildep. Bulaksumur, Yogyakarta: Gadjah Mada Univ. Press, 1988.

Sugiyono. Metode Penelitian Kualitatif. Cet.4. Bandung: Alfabeta, 2021.

Suyatmi, Titiek. Sastra Perbandingan. Yogyakarta: Universitas Ahmad Dahlan Press, 2008.

Wellek, Rene, dan Austin Warren. Teori Kesusastraan. Cet. 3. Jakarta: Gramedia Pustaka Utama, 1993. 